\title{
Kokonaisvaltainen johtaminen maitotilayrityksissä: maitotilayrittäjien ja sidosryhmien näkemyksiä
}

\author{
Margit Närvä ${ }^{1}$, Matti Ryhänen ${ }^{1}$, Jyrki Rajakorpi ${ }^{1} \&$ Timo Sipiläinen ${ }^{2}$ \\ ${ }^{1}$ Seinäjoen ammattikorkeakoulu, SeAMK Ruoka, PL 412, 60101 Seinäjoki \\ etunimi.sukunimi@seamk.fi \\ ${ }^{2}$ Helsingin yliopisto, Taloustieteen osasto, PL 27, 00014 Helsingin yliopisto \\ timo.sipilainen@helsinki.fi
}

\section{TIIVISTELMÄ}

Aiemmissa tutkimuksissa on todettu, että suomalaisissa maatalousyrityksissä strateginen johtaminen vaatii kehittämistä. Strategian luonnista ja käytäntöön viennistä on kuitenkin olemassa vain niukalti tutkimustietoa. Maitotilayrityksiin soveltuva kokonaisvaltainen johtaminen pitää sisällään strategisen ajattelun ja analyysin, strategisen suunnittelun ja johtamisen sekä strategian käytäntöön viennin. Kokonaisvaltainen johtaminen on pitkän ja lyhyen aikavälin johtamista yhtenä kokonaisuutena, missä pitkän aikavälin tavoitteita toteutetaan myös lyhyen aikavälin johtamisella.

Tutkimuksessa tarkastellaan, miten strateginen ajattelu ja analyysi toteutuivat maitotilayrityksissä, millaista tavoitteiden asettaminen, yritystoiminnan suunnittelu ja suunnitelmien käytäntöön vienti oli sekä miten maitotilayritysten kokonaisvaltaista johtamista voidaan edistää.

Lähestymistavaksi valittiin laadullinen tutkimus ja aineistot kerättiin teemahaastatteluin. Teemahaastattelu tehtiin 40:1le tuotantoa viime aikoina kehittäneelle tai kehittää aikovalle maitotilayrittäjälle ja 12:1le sidosryhmien edustajalle. Teemahaastattelut toteutettiin kevättalven ja kesän 2018 aikana.

Sidosryhmien edustajien näkemyksissä korostui, että maitotilayrittäjät ovat heterogeeninen joukko. Tulosten mukaan maitotilayrittäjät ajattelevat strategisesti, mutta määrämuotoista ja systemaattista kokonaisvaltaista johtamista maitotilayrittäjät eivät juurikaan hyödynnä. Ympäristön ja sisäisten resurssien analysointia ei tehdä systemaattisesti. Kirjallisia pitkän aikavälin suunnitelmia ei yleensä laadita. Pitkän aikavälin kirjallinen suunnittelu liittyy lähinnä investointien suunnitteluun ja toteuttamiseen. Myös tavoitteiden asettamisessa on kehitettävää. Maitotilayrittäjillä voi olla mietittynä pitkän aikavälin tavoitteita, mutta täsmällisiä taloudellisia tavoitteita on asetettu vain vähän. Maitotilayrittäjien huomio painottuu operatiiviseen suunnitteluun ja johtamiseen sekä käytännön töiden tekemiseen. Erityisesti strategisen johtamisen hallitseminen vaatii kehittämistä. Keskityttäessä yksittäisiin osa-alueisiin tai operatiivisiin asioihin, kokonaiskuva jää helposti taka-alalle. Osa maitotilayrittäjistä piti suunnittelua ja systemaattista suunnitelmien toteutumisen seurantaa tarpeellisena, mutta koki päivittäisten töiden määrän olevan niin iso, että siihen ei tahdo olla aikaa. Sidosryhmien edustajien mukaan maitotilayrittäjän on hallittava tulevaisuudessa strategista suunnittelua ja johtamista. Kokonaisvaltaisen johtamisen avuksi tarvitaan uusia työkaluja, jotka auttavat maitotilayrittäjää johtamaan yritystään kokonaisvaltaisesti.

Asiasanat: maitotilayrittäjä, johtaminen, suunnittelu 


\section{Johdanto}

Maitotilayritysten strategian luomisesta ja käytäntöön viennistä on olemassa vain niukalti tutkimustietoa. Aiemmissa tutkimuksissa on kuitenkin todettu, että suomalaisissa maitotilayrityksissä strateginen johtaminen vaatii kehittämistä (ks. esim. Närvä ym. 2008, Ryhänen ja Laitila 2012, 2014). Tässä artikkelissa käsiteltävä maitotilayrityksiin soveltuva kokonaisvaltainen johtaminen pitää sisällään strategisen ajattelun ja analyysin, strategisen suunnittelun ja johtamisen sekä strategian käytäntöön viennin. Kokonaisvaltainen johtaminen on siis pitkän ja lyhyen aikavälin johtamista yhtenä kokonaisuutena, missä pitkän aikavälin tavoitteita toteutetaan myös lyhyen aikavälin johtamisella.

Kuvassa 1 on esitetty tässä artikkelissa käytetyn käsitteen, kokonaisvaltainen johtaminen, osa-alueet. Strategiaprosessi lähtee liikkeelle maitotilayrittäjän kyvystä ajatella strategisesti. Strategian laadinnan lähtökohtana on toimintaympäristön analysointi ja oman maitotilayrityksen resurssien tuntemus. Strategian luonti -vaiheessa päätetään missio (arvot, toiminta-ajatus, visio), tehdään strategiset valinnat ja mietitään tavoitteet ja strategia, millä ne saavutetaan. Strategian käytäntöön vienti on tärkeä osa strategiaprosessia. Siinä operatiivinen johtaminen ja päivittäiset toimet saatetaan tukemaan valittua strategiaa.

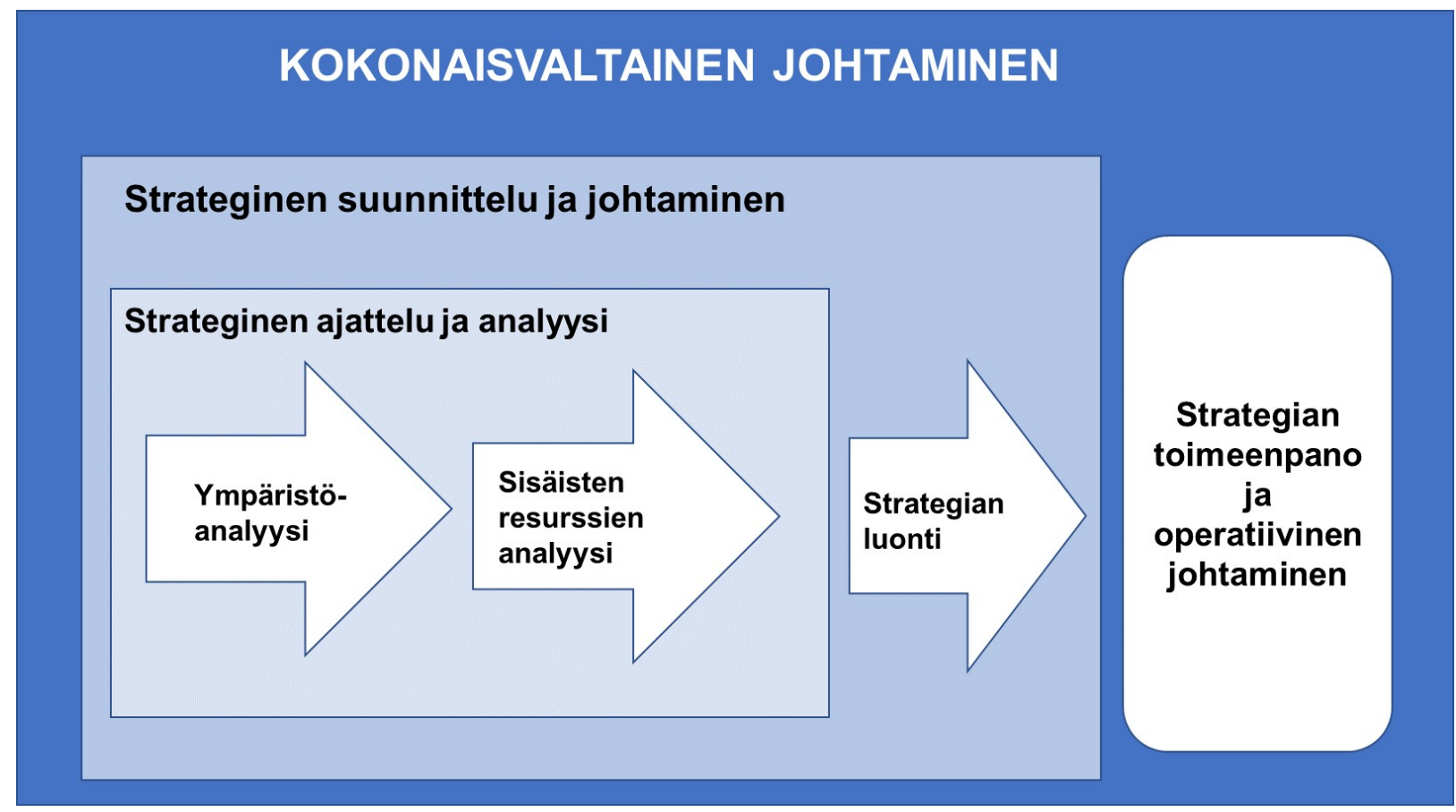

Kuva 1. Kokonaisvaltaisen johtamisen osa-alueet (Närvä ym. 2019)

Tämän artikkelin tavoitteena oli tutkia kokonaisvaltaisen johtamisen nykytilaa ja tulevaisuutta maitotilayrityksissä. Artikkelissa vastataan seuraaviin kysymyksiin:

- Miten strateginen ajattelu ja analyysi toteutuivat maitotilayrityksissä?

- Millaista tavoitteiden asettaminen oli maitotilayrityksissä?

- Miten yritystoiminnan suunnittelu ja suunnitelmien käytäntöön vienti tapahtui?

- Miten maitotilayritysten kokonaisvaltaista johtamista voidaan edistää?

Kysymyksiin haetaan vastauksia maitotilayrittäjien ja heidän sidosryhmien edustajien näkemyksien perusteella. Sidosryhmien edustajien näkemyksiä haetaan, koska aikaisempien tutkimusten perusteella (esim. Hurmerinta-Peltomäki ja Nummela 2004) tiedetään, että yrittäjät eivät välttämättä tunnista oman toimintansa kehittämiskohteita.

\section{Materiaali ja menetelmät}

Kirjallisuuteen perehtymisen ja kokemuksen perusteella tiedettiin jo ennalta, että maitotilayritysten kokonaisvaltaisesta johtamisesta on vain vähän tutkittua tietoa saatavilla. Tieto, joka oli saatavilla, painottui joko strategisen tai operatiivisen johtamisen näkökulmaan. Kokonaisvaltaisen johtamisen aihe 
on moni-ilmeinen, haastava ja hankalasti kokonaisuudessaan ymmärrettävissä. Tämän vuoksi aihetta päätettiin tutkia kvalitatiivisella tutkimusotteella. (vrt. Hirsjärvi ym. 2009, Nuthall 2011) Aineiston keruumenetelmäksi valittiin teemahaastattelut. Tutkimuksessa kerättiin kaksi eri teemahaastatteluaineistoa.

Ensimmäinen teemahaastatteluaineisto koostui 40 maitotilayrityksen maitotilayrittäjille tehdyistä teemahaastatteluista. Haastateltaviksi valittiin hiljattain yritystoimintaansa kehittäneitä tai kehittämistä suunnittelevia maitotilayrittäjiä. Maitotilayrittäjät valittiin yhteistyössä hankkeessa mukana olevien meijereiden ja Maitovaltuuskunnan kanssa. Haastateltavia maitotilayrittäjiä valittiin eri kokoisista maitotilayrityksistä, 11 haastatellulla oli alle 60 lehmää, 18:1la 60-120 lehmää ja 11:1la yli 120 lehmää. Haastateltavia valittiin eri puolelta Suomea: 19 Etelä-Pohjanmaalta, yhdeksän Itä-Suomesta, kuusi Etelä-Suomesta ja kuusi Pohjois-Suomesta.

Toinen haastatteluaineisto koostui maitotilayrittäjien sidosryhmien edustajille tehdyistä haastatteluista. Sidosryhmän edustajia haastateltiin yhteensä 12. Haastatellut sidosryhmän edustajat ovat työssään tekemisissä maitotilayrittäjien kanssa. Haastateltuja valittiin eri organisaatioista, kuten pankeista, meijeristä, hallinnosta, neuvonnasta ja yhdistyksistä.

Molemmat haastatteluaineistot kerättiin vuonna 2018. Teemahaastatteluiden rungot suunniteltiin huolella. Niiden suunnitteluun osallistui useita tutkijoita ja haastattelukysymyksiin pyydettiin kommentteja hankkeen ohjausryhmältä. Haastattelurungot myös testattiin. Haastattelijoina toimivat hankkeen tutkijat sekä haastatteluiden tekemiseen koulutetut maatalousalan korkeakouluopiskelijat. Haastattelut nauhoitettiin ja litteroitiin. Tutkijat analysoivat haastattelut hyödyntäen laadullista sisällönanalyysiä. Osin hyödynnettiin myös määrällistä analyysiä laskemalla frekvenssejä.

Tässä artikkelissa vertaillaan maitotilayrittäjien ja sidosryhmän edustajien näkemyksiä. Kokonaisvaltaisella johtamisella kannattavuutta maidontuotantoon -julkaisun (ks. Ryhänen ja Närvä 2019) luvussa 3 on kerrottu yksityiskohtaisesti maitotilayrittäjien haastatteluiden tuloksista ja luvussa 4 sidosryhmien edustajien haastatteluiden tuloksista.

\section{Tulokset}

Sekä maitotilayrittäjien että sidosryhmän edustajien haastatteluiden mukaan maitotilayrittäjät eivät tehneet strategisista analyysiä systemaattisesti. Toimintaympäristöä seurattiin pääosin ammattilehdistä, internetistä, keskustelemalla muiden maatalousyrittäjien kanssa, meijerin kautta, omien ja tuttujen luottamustoimien kautta sekä neuvonnalta saadun tiedon avulla. Systemaattinen tiedonhaku ja analysointi oli puutteellista. Sidosryhmien edustajien mukaan maitotilayrittäjät seurasivat vaihtelevasti toimintaympäristöä. Toimintaympäristön seuraamista rajoitti heidän mukaansa maitotilayrittäjien ajan puute ja osalla maitotilayrittäjistä osaamisen puute.

Maitotilayrittäjien arvio vahvuuksista ja heikkouksista perustui useimmiten omaan kokemukseen ja näkemykseen. Arvioinnin pohjana käytettiin pääosin tuotannollisia tunnuslukuja. Taloudellisia vahvuuksia ja heikkouksia maitotilayrittäjät arvioivat toteutuneen tuloksen perusteella, mutta he eivät kuitenkaan määritelleet taloudellista tulosta selkeästi. Taloudellisten vahvuuksien ja heikkouksien arviointi perustui myös maitotilayrittäjien tuntemukseen, miten oli pärjätty. Osa haastatelluista maitotilayrittäjistä kuului kannattavuuskirjanpitoon, jolloin he saivat sieltä vertailutietoa. Omia vahvuuksia ja heikkouksia peilattiin myös siihen, mitä kommentteja oli kuultu sidosryhmiltä oman maitotilayrityksen tilanteesta. Systemaattinen omien resurssien arviointi sekä vertailutiedon haku ja tietojen analysointi olivat puutteellisia. Myös sidosryhmien edustajien näkemyksissä nousi esille, että maitotilayrittäjät arvioivat liian vähän yrityksensä vahvuuksia ja heikkouksia. He olivat huomanneet, että maitotilayrittäjät käyttävät arvioinnissa perinteisiä tuotannollisia ja fyysisiä mittareita, kuten keskituotosta ja yrityskokoa. Talouteen liittyviä asioita arvioidaan sidosryhmien edustajien mielestä liian vähän. Maitotilayrittäjillä on heidän mukaansa vaikeuksia hahmottaa, miten eri toimet vaikuttavat taloudelliseen tulokseen. He korostivat maitotilayrittäjien osaamisen olevan yrityksen keskeisin resurssi.

Suurella osalla haastatteluista maitotilayrittäjistä pitkän aikavälin tavoitteena oli yritystoiminnan kehittäminen. Valtaosa heistä aikoi kehittää maitotilayritystään investointien avulla. Taloudellisia tavoitteita ei ollut määritelty kuitenkaan täsmällisešti. Maitotilayrittäjät käsittelivät taloudellisia asioita 
yleensä maksuvalmiuden näkökulmasta, mutta kannattavuusnäkökulma jäi puutteelliseksi. Sidosryhmien edustajien mukaan osa maitotilayrittäjistä ei ole miettinyt tavoitteita, mutta osalla heistä oli selkeät tavoitteet yrityksen kehittämiseksi. Heidän mukaansa maitotilayrittäjien taloudelliset tavoitteet liittyivät usein omaan ja perheen toimeentuloon sekä lainojen takaisinmaksun aikatauluun.

Maitotilayrittäjät mainitsivat tekevänsä erilaisia tuotannollisia suunnitelmia, kuten ruokintasuunnitelma, viljelysuunnitelma, jalostussuunnitelma ja töiden suunnittelu. Talouden suunnitteluun liittyen tehtiin Likvi- ja investointisuunnitelmia. Osa maitotilayrittäjistä teki myös budjetointia. Maitotilayrittäjien haastatteluiden mukaan kirjallisia pitkän aikavälin suunnitelmia ei juurikaan laadittu. Pitkän aikavälin kirjallinen suunnittelu liittyi lähinnä investointien suunnitteluun ja toteuttamiseen. Myös sidosryhmien edustajien mukaan maitotilayrittäjät tekivät eniten lyhyen aikavälin suunnittelua. Tähän onkin olemassa hyviä apuvälineitä ja työkaluja.

Sidosryhmien edustajien mielestä valtaosa maitotilayrittäjistä suunnittelee liian vähän yrityksensä toimintaa pitkälle aikavälille. Heidän mukaansa kokonaisvaltainen johtaminen toteutuu maitotilayrityksissä keskimäärin heikosti. Sekä maitotilayrittäjät että sidosryhmien edustajat näkivät tulevaisuudessa menestyvän sellaisen maitotilayrityksen, jossa maitotilayrittäjä hakee tietoa, asettaa selkeät tavoitteet, seuraa tuloksia ja hallitsee yrityskokonaisuuden.

\section{Johtopäätökset}

Sidosryhmien edustajat korostivat, että maitotilayrittäjät ovat heterogeeninen ryhmä. He korostivat myös maitotilayrittäjien osaamisen tärkeyttä. Sidosryhmän edustajien mukaan tulevaisuudessa kokonaisvaltaisen johtamisen hallitseminen on välttämätöntä. Myös maitotilayrittäjät kertoivat, että tulevaisuudessa menestyy maitotilayritys, jossa on asetettu pitkälle tulevaisuuteen selkeät tavoitteet, joita kohti pyritään määrätietoisesti, ja tavoitteiden toteuttamista seurataan. Tällä hetkellä kokonaisvaltaista johtamista ei hallita maitotilayrityksissä, vaan se vaatii kehittämistä.

Maitotilayrittäjien taloudellisen osaamisen ja kokonaisvaltaisen johtamisen kehittämiseksi tarvitaan työkaluja, neuvontaa, koulutusta ja valmennusta. Myös vertaistuki ja benchmarking koetaan tärkeiksi. Eri sidosryhmien on kehitettävä tarjoamiaan palveluja ja henkilöstön osaamista, jotta he kykenevät tukemaan maitotilayrittäjiä heidän vastatessa tulevaisuuden toimintaympäristöstä nouseviin uusiin haasteisiin.

\section{Kirjallisuus}

Hirsjärvi, S., Remes, P. \& Sajavaara, P. 2009. Tutki ja kirjoita. 15. p. Helsinki: Tammi.

Hurmerinta-Peltomäki, L. \& Nummela, N. 2004. From temporary support to systematic resource development: expert services from an SME perspective. Journal of Small Business and Enterprise Development; Bradford 11: 233-243. https://doi.org/10.1108/14626000410537173

Nuthall, P.L. 2011. Farm Business Management. Analysis of Farming Systems. Oxfordshire, UK. CAB International. 453 p. ISBN 978-1-84593-839-0.

Närvä, M., Ryhänen, M., Veikkola, E., \& Vuorenmaa, T. 2008. Esiselvitys maidontuotannon kehittämiskohteista: loppuraportti. Seinäjoki: Seinäjoen ammattikorkeakoulu. Seinäjoen ammattikorkeakoulun julkaisusarja B. Raportteja ja selvityksiä 36 .

Ryhänen, M. \& Laitila, E. 2012. (toim.) Yhteistyö ja resurssit maitotiloilla: Verkostomaisen yrittämisen lähtökohtia ja edellytyksiä. Seinäjoki: Seinäjoen ammattikorkeakoulu. Seinäjoen ammattikorkeakoulun julkaisusarja B. Raportteja ja selvityksiä 59 .

Ryhänen, M. \& Laitila, E. (toim.) 2014. Yhteistyö ja verkostosuhteet. Strateginen tarkastelu maidontuotantoon sovellettuna. Seinäjoen ammattikorkeakoulun julkaisusarja A. Tutkimuksia 19: 1-204. https://doi.org/10.33354/smst.75283

Närvä, M., Ryhänen, M., Rajakorpi, J. \& Sipiläinen, T. 2019. Kokonaisvaltaisen johtamisen nykytila maitotilayrityksissä. Teoksessa: Ryhänen, M. \& Närvä, M. (toim.). 2019. Kokonaisvaltaisella johtamisella kannattavuutta maidontuotantoon. Seinäjoen ammattikorkeakoulun julkaisusarja A. Tutkimuksia 31: 29-54. https://doi.org/10.33354/smst. 73223 